\title{
UJI KINERJA MEMBRAN NANOFILTRASI ZEOLIT UNTUK MENAPIS NITRAT DAN AMONIUM AIR LIMBAH PRODUKSI TAHU
}

\author{
TEST PERFORMANCE OF ZEOLITE NANOFILTRATION \\ MEMBRANES TO SCREEN FOR NITRATE AND AMMONIUM \\ TOFU PRODUCTION WASTEWATER
}

\author{
Andriono Sapto Nugroho, Alia Damayanti \\ Jurusan Teknik Lingkungan, Institut Teknologi Sepuluh November Surabaya \\ Email : lia@its.ac.id \\ andriono11@mhs.enviro.its.ac.id
}

\begin{abstract}
Abstrak
Tujuan dari penelitian ini adalah mengidentifikasi proses sintesis serta karakteristik membran nanofiltrasi dengan bahan baku zeolit alam secara spesifik serta mencari efektifitas kinerja zeolit sebagai membran nanofiltrasi untuk menurunkan kadar nitrat dan amonium dalam limbah cair tahu yang ada di Surabaya. Metode yang digunakan dalam mengurangi bahkan menghilangkan nitrat dan amonium serta dapat mengoptimalkannya, adalah dengan menentukan ukuran partikel zeolit 40 mesh serta durasi proses centrifuge selama 10 menit dengan penambahan $\mathrm{NH}_{4} \mathrm{Cl}$ sebagai porogen dan penambahan lapisan pendukung PEG 400 sebagai kekuatan membran.

Kinerja membran zeolit nanofiltrasi sangat baik dan efektif dalam menapis nitrat dan amonium, dimana permeabilitas membran zeolit nanofiltrasi tertinggi pada ukuran partikel 40 mesh dengan durasi centrifuge 10 menit dengan nilai $3.81 \mathrm{~L} / \mathrm{m}^{2}$.jam serta permselektivitas membran zeolit tertinggi dalam menapis nitrat pada ukuran partikel 40 mesh dengan durasi centrifuge10 menit dengan nilai $57.72 \%$ pada volume limbah $25 \%$ sedangkan permselektivitas membran zeolit tertinggi dalam menapis amonium pada ukuran partikel 40 mesh dengan durasi 10 menit dengan nilai $98.18 \%$ pada volume limbah $75 \%$.
\end{abstract}

Kata kunci : Limbah cair tahu, membran, nanofiltrasi, pengolahan air, zeolit,

Abstract

The purpose of this study is identifying the synthesis and characteristics of nanofiltration membranes with raw materials and natural zeolite specifically looking for performance effectiveness of zeolite as a nanofiltration membrane to reduce levels of nitrate and ammonium tofu production wastewater. The method used to reduce or even eliminate nitrate and ammonium and be able to optimize it, is to determine the size of the zeolite particles 40 mesh as well as the duration of the centrifuge for 10 minutes with the addition of $\mathrm{NH}_{4} \mathrm{Cl}$ as porogen and the addition of PEG4OO as the strength of the supporting layer membrane

Zeolite nanofiltration membrane performance is very good and effective in sifting nitrate and ammonium, where zeolite nanofiltration membrane permeability at the highest particle size of 40 mesh with a centrifuge duration of 10 minutes with a value of $3.81 \mathrm{~L}^{2}{ }^{2}$.jam and the highest permselektivitas zeolite membranes filter out nitrates in the particle size of 40 mesh with centrifuge10 minutes duration with a value of 57.72\% on volume of waste $25 \%$ while the highest zeolite membranes permselektivitas ammonium percolate on 40 mesh particle size with a duration of 10 minutes with a value of $98.18 \%$ on volume of waste $75 \%$.

Keywords: membrane, nanofiltration, water treatment, wastewater tofu, zeolites 


\section{PENDAHULUAN}

Polutan organik yang terbuang ke badan air dapat mengakibatkan menurunnya kualitas air dan daya dukung lingkungan perairan di sekitar industri tahu. Penurunan daya dukung lingkungan tersebut dapat menyebabkan kematian organisme air, terjadinya alga blooming sehingga menghambat pertumbuhan tanaman air lainnya dan menimbulkan bau (Rossiana, 2006). Karakteristik limbah cair tersebut apabila dibandingkan dengan KepMenLH No. 51 tahun 1995 tentang Baku Mutu Limbah Cair Bagi Kegiatan Industri telah melampaui baku mutu.

Pada umumnya, industri tahu mengolah limbah cair yang dihasilkan melalui proses anaerobik. Dengan proses tersebut efisiensi pengolahan sekitar 70\%-80\%, sehingga air yang diolah masih mengandung kadar pencemar organik cukup tinggi serta menimbulkan bau yang kurang sedap. Maka dari itu limbah yang diolah dengan menggunakan unit anaerobik kurang efektif dan membutuhkan lahan yang cukup besar, selain itu limbah cair yang sudah diolah belum memenuhi baku mutu (Herlambang, 2002). Kemudian pada tahun 2007, oleh Kaswinarni, menerapkan sistem pengolahan limbah dengan sistem kombinasi anaerob-aerob dalam penyempurnaan hasil akhir pengolahan limbah cair tahu tanpa menimbulkan bau.

Metode arang aktif dengan menggunakan ampas kopi sebagai adsorben atau bahan penyerap (Sugiharto, 1987) yang kemudian oleh Irmanto dan Suyata (2009) digunakan untuk pengolahan limbah cair tahu dalam menurunkan kadar nitrat dan amonium. Sebelumnya, pada tahun 2007, Irmanto dan Suyata melakukan suatu penelitian dengn menggunakan sistem zeolit teraktivasi dan terimpregnasi $\mathrm{TiO}_{2}$ dalam menurunkan kadar amonium, nitrat dan nitrit pada limbah cair tahu.

Sedangkan Myrasandri dan Syafila (2012) menggunakan ABR (Anaerobic Buffled Reactor) dalam penelitian untuk mendegradasi senyawa organik dalam limbah cair tahu. Penggunaan arang tempurung sebagai absorben dengan enceng gondok secara fitoremediasi dalam pengolahan limbah tahu (Alimsyah dan Damayanti, 2013).

Membran dengan pendorong tekanan adalah teknologi membran yang paling banyak digunakan dalam aplikasi pengolahan air (Ulbricht, 2006), Meskipun, penggunaan pemisahan gas, pervaporasi, dan membran electrochemical untuk pemisahan industri dan lingkungan juga telah meningkat secara dramatis dalam beberapa dekade terakhir (Bernardo dkk., 2009).

Keunggulan penggunaan membran terdapat pada pengoperasian pengolahan air limbah yaitu tidak membutuhkan energi yang terlalu besar karena tidak melibatkan perubahan fase dan tidak terlalu menggunakan energi dalam bentuk panas sehingga komponen di dalamnya dapat dipertahankan (Aspiyanto dan Susilowati, 2007). Akan tetapi masih banyak yang beranggapan bahwa teknologi membran relatif mahal karena berasal dari luar negeri, sehingga perlu dibuat suatu rekayasa membran yang bahan bakunya murah dan mudah didapat seperti zeolit. Akhir-akhir ini membran zeolit banyak memperoleh perhatian para peneliti karena struktur porinya yang beragam, stabilitasnya terhadap panas dan kekuatan mekanisnya yang baik serta tahan terhadap lingkungan kimia yang ekstrim. Struktur pori zeolit yang berbeda-beda membuat zeolit banyak digunakan untuk pemisahan berbagai molekul kecil (Shan dkk., 2004). Sedangkan untuk jenis membran yang sering digunakan adalah membran nanofiltrasi. Membran nanofiltrasi mempunyai ukuran pori sebesar $0.001 \mu \mathrm{m}$ dan dapat menyaring air limbah dengan kadar organik yang tinggi. Membran nanofiltrasi yang dihasilkan akan dijalankan pada sebuah reaktor dengan aliran cross flow untuk mencegah fouling dini.

\section{METODA}

Penelitian ini dilakukan selama 5 bulan, mulai bulan September 2013 - Januari 2014 di Laboratorium Teknik Lingkungan ITS. 


\section{Prosedur dalam penelitian}

Pembuatan Membran zeolit nanofiltrasi dengan variasi ukuran partikel awal zeolit 40 mesh dengan metode alkalifussion, kemudian ditambahkan 2-propanol $35 \mathrm{ml}$ dilanjutkan dengan proses centrifuge kecepatan $600 \mathrm{rpm}$ pada masing-masing durasi 10 menit. Selanjutnya, campuran tersebut ditambahkan 3, 5 gram $\mathrm{NH}_{4} \mathrm{Cl}$ sebagai surfaktan kationik yang telah dilarutkan dalam $300 \mathrm{ml}$ aquades. Campuran tersebut kemudian diaduk dengan magnetic stirrer selama 1 jam agar terbentuk pori membran yang berukuran nano (Chowdhury dkk, 2006). Proses pencetakan membran diawali dengan menambahkan, $5 \mathrm{ml}$ PEG 400 ke dalam campuran. Selanjutnya membran dicetak menggunakan cawan petri dan dijemur di bawah sinar matahari sampai kering selama 30 jam. Membran dioven pada suhu $70^{\circ} \mathrm{C}$ selama 1 jam untuk memperkuat struktur membran dan tidak mudah sobek.

Reaktor dengan aliran cross flow sebagai alat uji kinerja membran zeolit nanofiltrasi yang telah dibuat. Seperti tampak Gambar 1. di bawah ini.

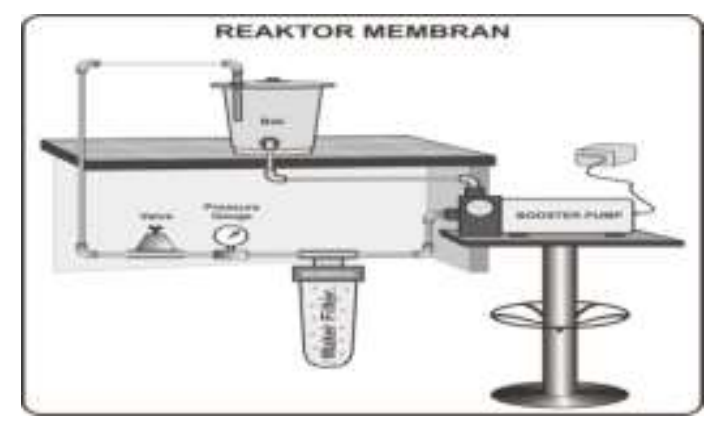

Gambar 1. Reaktor Membran.

Pengujian untuk mendapatkan koefisien rejeksi (R\%) dilakukan pada menit ke-80 yaitu hasil permeat pada proses penyaringan. Sedangkan dalam memperoleh nilai fluks dilakukan selama 80 menit, dan setiap selang 20 menit diambil permeatnya dan diukur volumenya. Reaktor dengan aliran cross flow dalam pengujian membran zeolit nanofiltrasi dengan ukuran partikel 40 mesh dengan durasi centrifuge 10 menit pada masing-masing variasi volume limbah cair tahu dengan aquadest, yaitu dengan perbandingan $\quad 75 \%: 25 \%: 50 \%: 50 \%$; 25\%:75\%. Variasi uji membran dapat dilihat pada Tabel 1. di bawah ini.

Tabel 1. Variasi Uji Membran

\begin{tabular}{ccc}
\hline $\begin{array}{c}\text { Ukuran } \\
\text { Partikel } \\
\text { Zeolit }\end{array}$ & $\begin{array}{c}\text { Durasi Centrifuge } \\
\text { pada 600 rpm }\end{array}$ & $\begin{array}{c}\text { Perbandingan } \\
\text { Volume limbah : } \\
\text { volume aquadest }\end{array}$ \\
\hline \multirow{3}{*}{40 mesh } & \multirow{2}{*}{10 menit } & $75 \%: 25 \%$ \\
& & $50 \%: 50 \%$ \\
$25 \%: 75 \%$
\end{tabular}

Analisis morfologi dilakukan dengan metode SEM (Scanning Electron Microscopy). Dengan uji ini dapat diketahui struktur permukaan dan penampang melintang suatu polimer menggunakan mikroskop elektron.

\section{HASIL DAN PEMBAHASAN}

Tahapan awal dalam proses penelitian ini, disamping menghasilkan membran zeolit nanofiltrasi (Gambar. 2) yang akan diuji pada reaktor dengan aliran cross flow adalah hasil analisis awal nitrat dan amonium pada limbah dengan variasi persentase volume limbah dengan volume aquadest. Seperti tampak pada Tabel 2 dan Tabel 3.

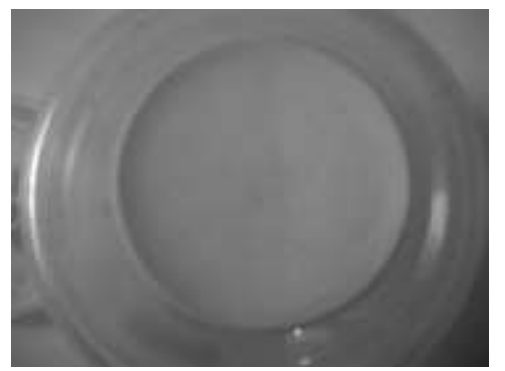

Gambar 2. Membran Zeolit Nanofiltrasi

Tabel 2. Hasil Analisis Awal Kadar Nitrat

\begin{tabular}{cc}
\hline $\begin{array}{c}\% \text { volume limbah : } \% \\
\text { volume aquadest }\end{array}$ & $\begin{array}{c}\text { Kadar Amonium } \\
(\mathbf{m g} / \mathbf{l})\end{array}$ \\
\hline $75: 25$ & 3.30 \\
$50: 50$ & 3.20 \\
$25: 75$ & 14.90 \\
\hline
\end{tabular}


Dilihat dari hasil penelitian awal kadar nitrat dalam sampel cair limbah tahu, terdapat perbedaan kadar/konsentrasi baik pada $25 \%$ volume limbah sampai pada $75 \%$ volume limbah. Dalam proses pengujian membran zeolit nanofiltrasi dari awal hingga akhir, sampel diambil terlebih dahulu dari pabrik produksi tahu yang kemudian disimpan dalam lemari es/frezeer.

Tabel 3. Hasil Analisis Awal Kadar Amonium

\begin{tabular}{cc}
\hline $\begin{array}{c}\text { \% volume limbah : \% } \\
\text { volume aquadest }\end{array}$ & $\begin{array}{c}\text { Kadar Amonium } \\
(\mathbf{m g} / \mathbf{l})\end{array}$ \\
\hline $75: 25$ & 11.00 \\
$50: 50$ & 15.50 \\
$25: 75$ & 12.80 \\
\hline
\end{tabular}

Pada tahap awal pengujian menggunakan 25\% volume limbah, diperoleh kadar nitrat yang tinggi yaitu $14.90 \mathrm{mg} / \mathrm{l}$. Kemudian dilanjutkan pada tahap kedua dengan menggunakan $50 \%$ volume limbah memperoleh kandungan nitrat $3.20 \mathrm{mg} / \mathrm{l}$. Kadar nitrat mengalami penurunan yang begitu besar, hal ini disebabkan oleh perlakuan/proses yang terjadi dalam limbah cair tahu tersebut. Perlakuan sampel limbah cair tahu antara lain :

1. Menyimpan di dalam lemari es/frezeer dengan suhu berkisar $8^{\circ} \mathrm{C}$,

2. Rentang waktu yang cukup lama dalam pengujian membran dengan variasi volume limbah.

Sehingga sampel limbah cair tahu dalam kondisi anaerob yang memungkinkan terjadinya proses denitrifikasi, yaitu proses reduksi nitrat menjadi nitrit dan kemudian diubah menjadi gas nitrogen. Tahap anaerobik yang melibatkan pengurangan $\mathrm{NO}_{3}{ }^{-}$untuk gas nitrogen oleh bakteri denitrifikasi. Denitrifikasi telah terbukti sebagai proses yang terjadi di luar penyaring dengan menggunakan zeolit (Booker dkk., 1995), di mana substrat (nitrat dan organik C) diperlukan untuk denitrifikasi (Wilson dkk., 1981). Hasil analisa awal amonium pada penelitian ini, dengan perlakuan sampel cair limbah tahu disimpan dalam lemari es/frezeer dengan suhu sekitar $8^{\circ} \mathrm{C}$ pada awal pengujian menunjukkan peningkatan kadar amonium dalam sampel pada $25 \%$ volume limbah dan $50 \%$ volume limbah. Terjadi peningkatan kadar amonium dengan peningkatan persentase volume limbah.

Hal ini disebabkan proses oksidasi tidak terjadi pada amonium atau dalam kondisi in aktif pada mikroorganisme yang ada serta rentang waktu yang cukup lama dalam pengujian membran pada $50 \%$ volume limbah dari $25 \%$ volume limbah selama dalam penyimpanan di lemari es. Tetapi kadar amonium pada persentase volume limbah $75 \%$ mengalami penurunan dari $50 \%$ volume limbah. Hal ini disebabkan antara lain, rentang waktu pengujian membran zeolit pada $50 \%$ volume limbah dengan $75 \%$ volume limbah pendek dan memungkinkan terjadi proses oksidasi di dalam limbah cair tersebut. Hal ini juga didukung adanya peningkatan kadar nitrat pada $75 \%$ volume limbah dari kadar nitrat $50 \%$ volume limbah. Terjadi oksidasi pada amonium menjadi nitrat. seperti reaksi dibawah ini :

$\mathrm{NO}_{2}^{-}+1 / 2 \mathrm{O}_{2} \Rightarrow \mathrm{NO}_{3}^{-} \quad \ldots \ldots \ldots \ldots \ldots$

$\mathrm{NH}_{4}^{+}+2 \mathrm{O}_{2} \Rightarrow \mathrm{NO}_{3}^{-}+2 \mathrm{H}^{+}+\mathrm{H}_{2} \mathrm{O} \ldots \ldots$.

Proses nitrifikasi yang terjadi adalah suatu proses konversi dari amonia menjadi nitrit yang kemudian menjadi nitrat yang dilakukan oleh bakteri autotropik dan heterotropik (Grady dan Lim (1980) dalam Said (2009)). Bahan organik berupa protein yang terdapat dalam limbah cair industri tahu terdekomposisi menjadi amonia dengan bantuan mikroorganisme pengurai yang terdapat dalam limbah cair industri tahu. Pada kondisi aerobik amonia teroksidasi menjadi nitrit, kemudian nitrit dioksidasi lagi menjadi nitrat (Irmanto dan Suyata, 2009). Hasil dari perhitungan koefisien rejeksi nitrat pada membran 40 mesh durasi centrifuge 10 menit dengan volume limbah $25 \%$ yang terbesar dengan nilai $57.72 \%$. Hal ini ditunjukkan pada Tabel 4. Dengan Konsentrasi awal atau $\mathrm{C}_{25-75}$ nitrat $14.90 \mathrm{mg} / \mathrm{l}$, pada pengambilan permeat menit ke-80. 
Tabel. 4. Pengaruh Ukuran Partikel Zeolit, Waktu Durasi Centrifuge dan Volume Air Limbah Terhadap Prosentase Removal Nitrat

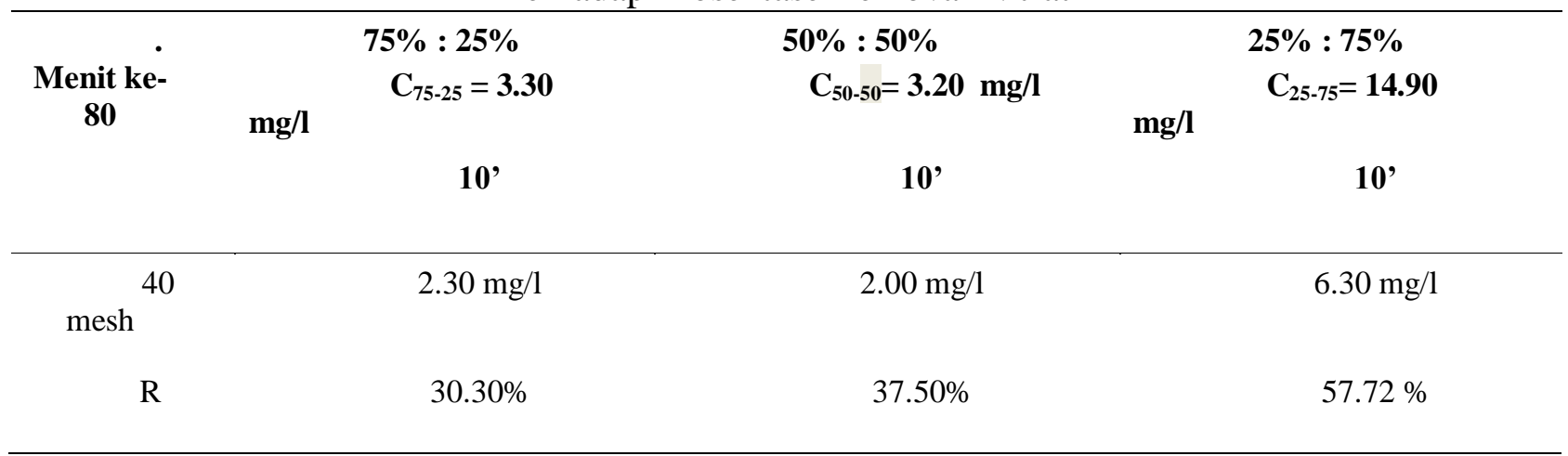

Keterangan Tabel 4 :

- $25 \%: 75 \% \Rightarrow$ volume limbah $75 \%$ dengan volume aquadest $25 \%$

- $\mathrm{C}_{25-75} \quad \Rightarrow \quad$ konsentrasi awal nitrat pada volume limbah $75 \%$ dengan volume aquadest $25 \%$

- $10^{\prime} \quad \Rightarrow \quad$ waktu durasi centrifuge selama 10 menit

- 40 mesh $\Rightarrow$ ukuran partikel 40 mesh

- $\mathrm{R} \quad \Rightarrow$ Koefisien Rejeksi

Ukuran partikel dari bubuk awal juga memiliki efek pada sifat pendukung membran, dimana Steenkamp dkk. (2001) dan Wang dkk. (1999), menyatakan bahwa semakin kecil ukuran partikel serbuk awal, maka semakin kecil poripori, permeabilitas serta porositas air rendah. Didukung oleh Li dkk. (2007), dan Dyer (1988) bahwa ukuran pori dan kepadatan kerangka adalah faktor utama yang menjadi perhatian ketika mempertimbangkan zeolit untuk pemisahan air, ukuran pori menentukan selektivitas ion dan kepadatan kerangka menentukan permeabilitas air. Ditinjau dari proses centrifuge, durasi 10 menit memperlihatkan hasil yang optimal pada proses kerja membran dalam menapis ion nitrat. Hal ini seperti yang dilakukan oleh Fatmasari (2012) dalam Puspayana dan Damayanti (2013).

Tabel 5. Pengaruh Ukuran Partikel Zeolit, Waktu Durasi Centrifuge dan Volume Air Limbah Terhadap Prosentase Removal Amonium.

\begin{tabular}{|c|c|c|c|}
\hline $\begin{array}{l}\text { Menit ke- } \\
80\end{array}$ & $\begin{array}{l}\quad 75: 25 \\
C_{75-25}=11.00 \mathrm{mg} / \mathrm{l} \\
10\end{array}$ & $\begin{array}{l}\quad 50: 50 \\
C_{50-50}=15.50 \mathrm{mg} / \mathrm{l} \\
10\end{array}$ & $\begin{array}{l}\quad 25: 75 \\
C_{25-75}=12.80 \mathrm{mg} / \mathrm{l} \\
10\end{array}$ \\
\hline 40 mesh & $0.20 \mathrm{mg} / \mathrm{l}$ & $9.50 \mathrm{mg} / \mathrm{l}$ & $6.90 \mathrm{mg} / \mathrm{l}$ \\
\hline $\mathrm{R}$ & $98.18 \%$ & $38.71 \%$ & $46.10 \%$ \\
\hline
\end{tabular}


Keterangan Tabel 5 :

- 75:25 $\quad \Rightarrow$ volume limbah $75 \%$ dengan volume aquadest $25 \%$

- $\mathrm{C}_{75-25} \quad \Rightarrow$ konsentrasi awal nitrat pada volume limbah $75 \%$ dengan volume aquadest $25 \%$

- $10^{\prime} \quad \Rightarrow$ waktu durasi centrifuge selama 10 menit

- 40 mesh $\quad \Rightarrow$ ukuran partikel 40 mesh

- $\mathrm{R} \quad \Rightarrow$ Koefisien Rejeksi

Sehingga durasi centrifuge (Fatmasari, 2012) memberikan hasil yang optimum. Sedangkan pada ukuran partikel 40 mesh diperlukan waktu durasi yang lebih lama yaitu 20 menit, untuk medapatkan kerapatan kerangka yang mempengaruhi selektivitas membran terhadap ion amonium ( Li dkk. (2007), dan Dyer (1988)). PEG sebagai anti fouling bekerja lebih optimal pada membran ini.

Koefisien rejeksi yang terbaik pada kondisi ini adalah membran 40 mesh durasi centrifuge 10 menit yaitu $98.18 \%$. Dengan konsentrasi awal atau $\mathrm{C}_{75-25}$ amonium $11.00 \mathrm{mg} / \mathrm{l}$, pada pengambilan permeat menit ke-80. Bisa dilihat pada Tabel 5. Seperti penjelasan pada penapisan nitrat, bahwa menurut Li dkk. (2007), dan Dyer (1988) bahwa ukuran pori dan kepadatan kerangka adalah faktor utama yang menjadi perhatian ketika mempertimbangkan zeolit untuk pemisahan air, ukuran pori menentukan selektivitas ion dan kepadatan kerangka menentukan permeabilitas air. Ukuran pori ditentukan oleh ukuran partikel serbuk awal (Steenkamp dkk. (2001) dan Wang dkk.
(1999)), sehingga dalam proses penapisan amonium yang optimal dengan menggunakan membran zeolit nanofiltrasi 40 mesh yang memiliki selektivitas terhadap ion amonium. Serta didukung centrifuge yang optimal pada durasi 10 menit (Fatmasari, 2012).

Pada Tabel 6 menunjukkan bahwa nilai fluks terbesar didapatkan pada membran ukuran partikel zeolit 40 mesh, durasi centrifuge 10 menit pada pengambilan pertama yaitu menit ke 20 sebesar $3.81 \mathrm{~L} / \mathrm{m}^{2}$.jam dan terjadi penurunan nilai fluks di setiap pertambahan waktu. Dalam proses pembuatan membran, memungkinkan kerja yang optimal sehingga distribusi pori dengan penambahan $\mathrm{NH}_{4} \mathrm{Cl}$ sebagai porogen merata (Puspayana dan Damayanti, 2013) serta penambahan PEG dengan yang optimal dalam mengurangi terjadinya proses fouling dini. Pada penelitian ini, Pengaruh fouling serta polarisasi (Ariyanti, 2009) pada mesh 40 dengan durasi 10 menit menunjukkan peningkatan yang cepat dalam proses penapisan. Sehingga permeabilitas membran rendah. Peran PEG sebagai anti fouling tidak bekerja secara maksimal.

Tabel 6. Nilai Fluks (J) pada Volume Air Limbah 25\% dan Aquadest $75 \%$

\begin{tabular}{llc}
\hline \multirow{2}{*}{ Menit ke- } & \multicolumn{2}{c}{$\mathbf{4 0}$ mesh 10 } \\
\cline { 2 - 3 } & volume $(\mathrm{ml})$ & Nilai Fluks \\
\hline 20 & 2.25 & 3.81 \\
40 & 2.00 & 1.71 \\
60 & 1.75 & 0.99 \\
80 & 1.30 & 0.55 \\
Rata-rata & & 1.77 \\
\hline
\end{tabular}




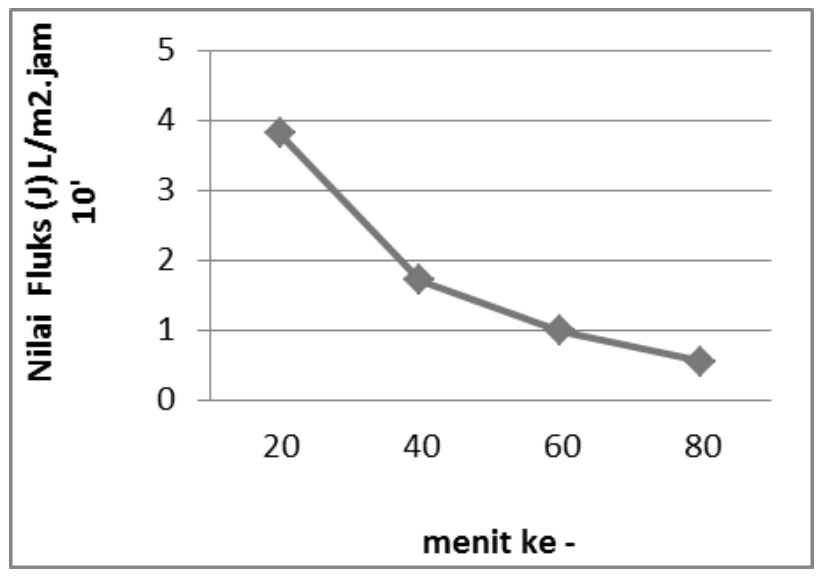

Gambar 3. Nilai Fluks (J) pada Ukuran Partikel Zeolit 40 mesh, Waktu Durasi Centrifuge 10 dan Volume Air Limbah $25 \%$.

Salah satu cara untuk mengetahui morfologi membran adalah dengan uji SEM. Dengan uji ini dapat diketahui struktur permukaan dan penampang melintang suatu membran menggunakan mikroskop elektron (Mulder, 1996). Analisa SEM menunjukkan bentuk dan perubahan atau morfologi permukaan dari sampel yang dianalisis. Pada prinsipnya bila terjadi perubahan suatu bahan misalnya perubahan struktur permukaan, maka bahan tersebut cenderung mengalami perubahan energi. Energi yang telah berubah tersebut dapat dipancarkan, dipantulkan, dan diserap serta diubah bentuknya menjadi fungsi gelombang elektron yang dapat ditangkap dan dibaca hasilnya (Mumpuni, 2011).

Pada penelitian ini, membran zeolit nanofiltrasi yang telah dibuat merupakan jenis membran anorganik berdasarkan morfologinya. Membran ini biasanya multi-lapis, yang berarti bahwa mereka yang terdiri satu atau lebih lapisan pendukung bagi lapisan atas. Lapisan pendukung (PEG) memberikan kekuatan mekanik sedangkan lapisan atas bertanggung jawab atas sifat pemisahan membran. Kekuatan lapisan pendukung harus stabil pada temperatur tinggi dan tahan terhadap pelarut agar dapat digunakan dalam jangka waktu yang panjang (Mabande dkk., 2004, De Vos dan Verweij, 1988). Dapat dilihat pada Gambar di bawah ini yang merupakan penampang melintang membran sebelum dan sesudah pengujian pada membran. Hasil SEM penampang melintang membran zeolit nanofiltrasi dengan perbesaran 200 kali. Pada gambar tersebut terdapat ronggarongga yang sangat kecil dan struktur membran terlihat asimetris. Dari Gambar yang ditampilkan di atas, membran yang dihasilkan dalam penelitian ini sebagai membran anorganik yang memiliki keung- gulan antara lain (Biesheuvel, 1999):

1. Partikel dapat tersebar secara efektif dalam fase cair dengan pengadukan.

2. Pencampuran partikel dapat berlangsung secara homogen.

3. Hasil sentrifuge dalam struktur padat, seragam, bebas cacat dan memiliki permukaan yang halus.

Sedangkan kekurangan dalam proses pembuatan membran ini adalah :

1. Waktu produksi lama karena pemisahan partikel cair

2. Segresi yang tidak diingikan akibat gravitasi.

Distribusi pori dapat dilihat pada gambar penampang melintang membran, merata pada seluruh bagian membran. Hal ini ditunjukkan adanya serat-serat pada bagian dalam, seperti pada Gambar 3. bagian samping (sesudah uji kinerja dalam reactor) menunjukkan adanya aliran air dalam hal ini adalah sebagai permeat. 


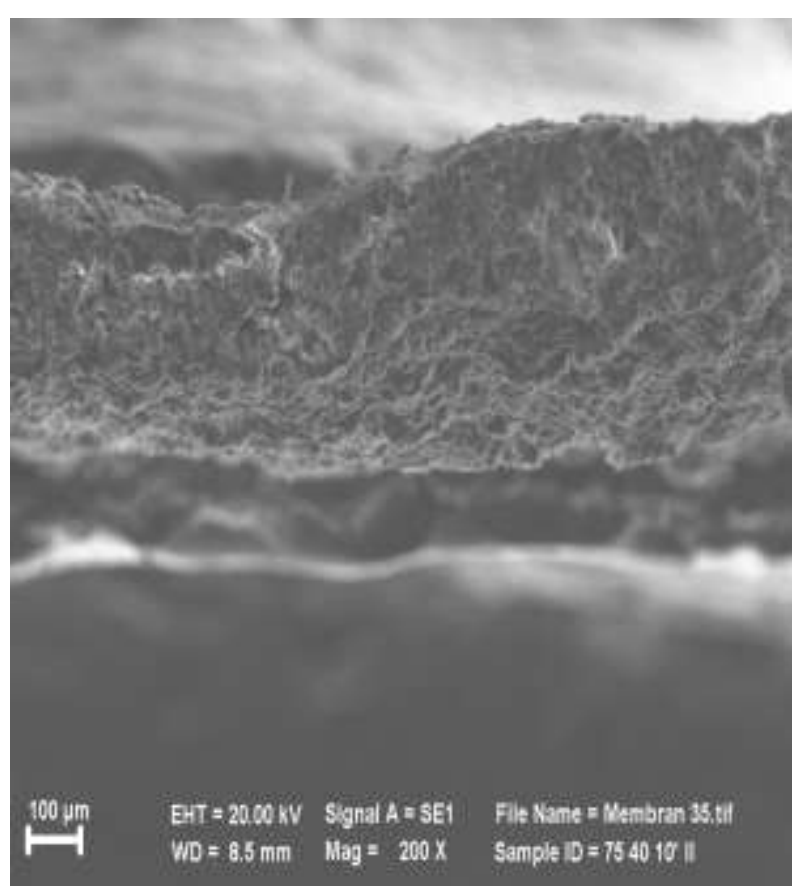

(a)

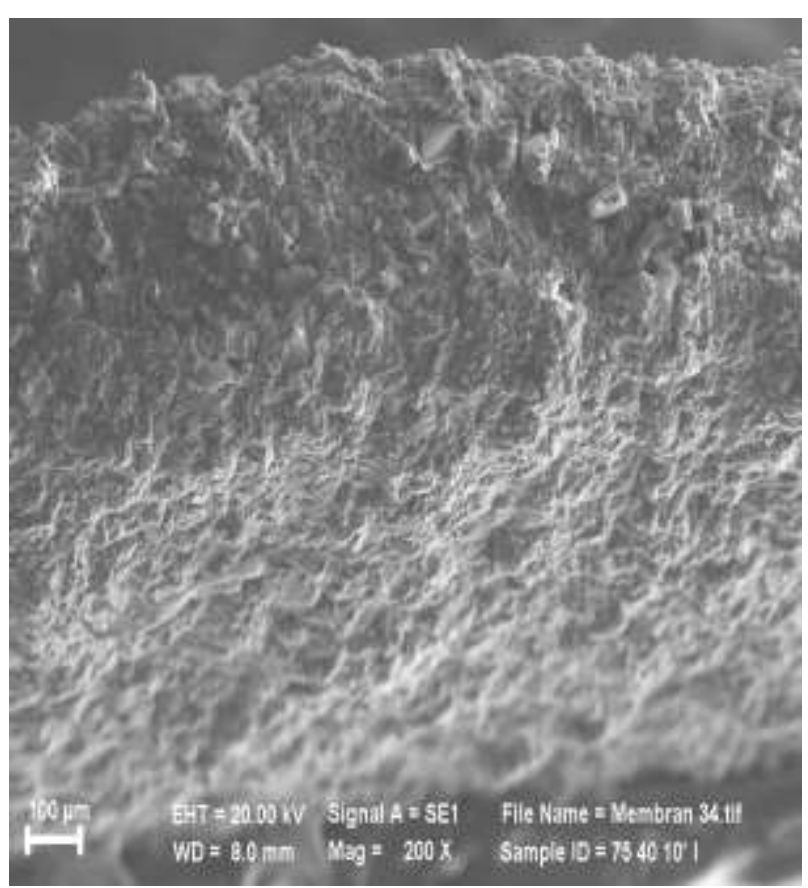

(b)

Gambar 3. Penampang melintang membran zeolit nanofiltasi pada ukuran 40 mesh, durasi centrifuge 10 menit pada $75 \%$ volume limbah dengan $25 \%$ volume aquadest.

Sebelum (a) dan sesudah (b) uji kinerja dalam reaktor.

Sebagaimana penelitian yang dilakukan Puspayana dan Damayanti (2013) dengan penambahan $\mathrm{NH}_{4} \mathrm{Cl}$ sebagai porogen yaitu pembentuk serta penyeragam pori dan juga penambahan PEG sebagai bahan organik pembentuk pori salah satunya yang dilakukan oleh Muliawati (2012) dengan Saljoughi (2010). Dalam proses pembuatan membran zeolit nanofiltrasi ini untuk membentuk permukaan yang halus serta merata dilakukan penambahan air serta pengadukan yang stabil sebelum membran dicetak seperti yang dilakukan oleh Puspayana dan Damayanti (2013).

Serta ditunjang proses centrufuge selama 10 menit yang merupakan durasi optimal dalam membentuk struktur membran yang padat dan seragam. Seperti terlihat pada Gambar di bawah ini, merupakan hasil analisis SEM pada permukaan membran zeolit nanofiltrasi sebelum dan sesudah uji pada reaktor. Dapat dilihat dengan jelas pada Gambar 4 , perbedaan membran sebelum dan sesudah uji pada reaktor menunjukkan adanya zat/partikel yang menempel pada membran.

Fouling dapat terjadi pada membran tetapi tidak hanya di bagian permukaan atas atau lapisan luar membran saja, tetapi juga terjadi pada bagian spinger atau lapisan dalam membran. Pengotor yang masuk kedalam lapisan dalam tersebut terjadi akibat adanya tekanan yang diberikan selama proses operasi membran, tekanan akan mendorong deposisi partikel pada permukaan membran atau lapisan atas untuk masuk ke dalam lapisan dalam membran (Notodarmojo dkk., 2004).

Hal ini dapat dilihat dari hasil fluks yang mengalami penurunan seiring dengan waktu berjalan. Untuk mengurangi terjadinya fouling, dilakukan penambahan PEG, sebagai anti fouling, seperti terdapat dalam Su dkk. (2009) yang menyebutkan bahwa PEG adalah senyawa biocompatible, highly hydrophilic dan anti fouling. 


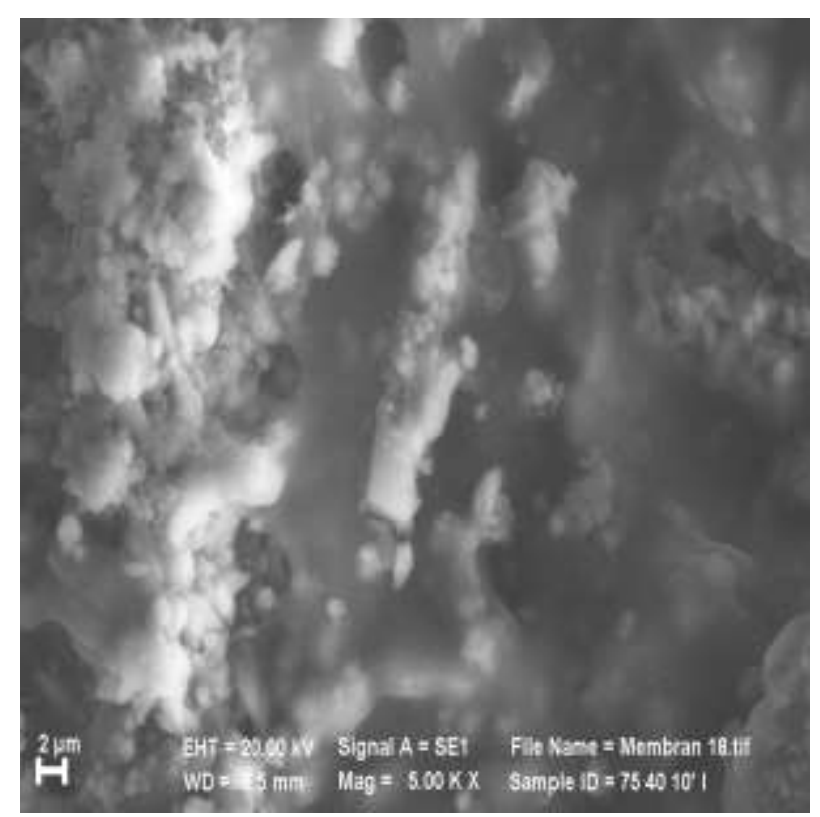

(a)

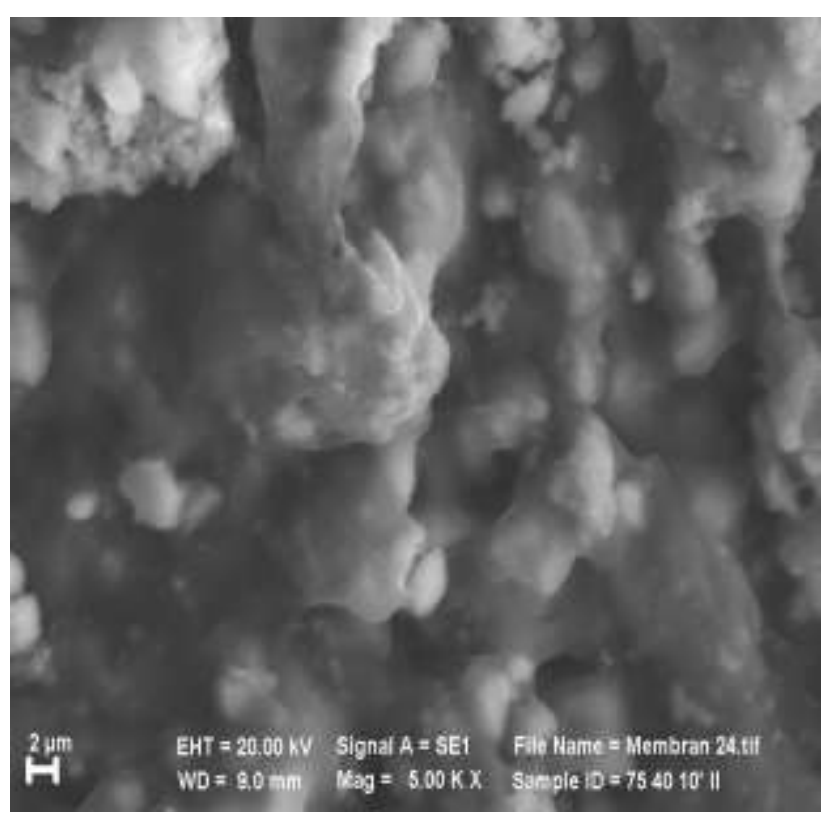

(b)

Gambar 4. Penampang permukaan membran zeolit nanofiltrasi ukuran 40 mesh, durasi centrifuge 10 menit pada $75 \%$ volume limbah dan $25 \%$ volume aquadest.(Perbesaran 5000 kali). Sebelum (a) dan sesudah (b) uji kinerja pada reactor.

\section{KESIMPULAN}

Setelah melalui proses penelitian dalam pembuatan dan menapis nitrat dan amonium pada limbah cair tahu dengan menggunakan membran zeolit nanofiltrasi maka dapat disimpulkan: Membran zeolit nanofiltrasi dapat dibuat pada variasi komposisi ukuran partikel 40 dengan berat $2.00 \mathrm{mg}$ melalui proses alkalifussion dengan penambahan $35.00 \mathrm{ml} \mathrm{2-}$ propanol durasi centrifuge 10 menit, penambahan $\mathrm{NH}_{4} \mathrm{Cl} 1.20 \%$ magnet stirer selama 1 jam, penambahan $2.00 \mathrm{ml}$ PEG 400, serta penambahan $30.00 \mathrm{ml}$ aquadest.

Hasil pengamatan dengan menggunakan SEM pada penampang melintang dan permukaan, terdapat rongga-rongga yang berdasarkan prinsip pemisahannya merupakan jenis membran asimetris dan berdasarkan morfologinya, merupakan jenis membran anorganik. Kinerja membran zeolit nanofiltrasi sangat baik dan efektif dalam menapis nitrat dan amonium, yaitu : Permeabilitas/fluks membran zeolit tertinggi pada ukuran partikel 40 mesh dengan durasi 10 menit dengan nilai 3.81 $\mathrm{L} / \mathrm{m}^{2}$.jam pada volume limbah $25 \%$ dan volume aquadest $75 \%$.

Permselektivitas/koefisien rejeksi (R\%) membran zeolit tertinggi dalam menapis amonium pada ukuran partikel 40 mesh dengan durasi 10 menit dengan nilai $98.18 \%$ pada volume limbah $75 \%$ dan volume aquadest $25 \%$. Permselektivitas/koefisien rejeksi (R\%) membran zeolit tertinggi dalam menapis nitrat pada ukuran partikel 40 mesh dengan durasi 10 menit dengan nilai $57.72 \%$ pada volume limbah $25 \%$ dan volume aquadest $75 \%$.

\section{DAFTAR PUSTAKA}

Alimsyah A. dan Damayanti A., 2013, Penggunaan Arang Tempurung Kelapa dan Eceng Gondok untuk Pengolahan Air Limbah Tahu denga Variasi Konsentrasi Teknik Lingkungan, Fakultas Teknik Sipil dan Perencanaan, Institut Teknologi Sepuluh Nopember (ITS). 
Ariyanti, D., 2009, Studi metode Autoflush: Pengendalian scaling pada system Membran Reverse Osmosis Skala Rumah Tangga, Universitas Diponegoro Semarang.

Aspiyanto, dan Susilowati, A., 2007, Microfiltration Membran Utilization in Preparation of Hydrolized

Bernardo, P., Drioli, E. and Golemme, G., 2009, Membran gas separation: A review/state of the art, Ind. Eng. Chem. Res. , 48, 4638-4663.

Biesheuvel, P.M., Ph.D., 1999, Porous ceramic membranes suspension processing, mechanical and transport properties, and application in the osmotic tensiometer, Summary, Universiteit Twente, The Nederlands

Booker, N.A.; Cooney,E.L.; Priestley,A.J. 1995 : A combined high rate adsorption process for enhanced sewage treatment. In : Proceedings of the $16^{\text {th }}$ Federal Convention, Australian Water and Wastewater Association, Sydney, Australia. Pp.645-652.

Chowdhury, S.R., Alisia, M.P., Dave, H.A.B., Johan, E., 2006, Influence of Porous Substrate on Mesopore Structure and Water Permeability of Surfactant Template Mesoporous Silica Membranes, Journal of Membrane Science 277: 6-10

De Vos, R.M., Verweij, H., 1998, Highselectivity, high-flux silica membranes for gas separation, Journal of Membrane Science, 279, 1710

Dyer, A., 1988, An Introduction to Zeolite Molecullar Sieve, Departement of Chemistry and Applied Chemistry, University of Salford. UK.

Fatmasari, S.R., 2012, Pemanfaatan Silika Sekam Padi Sebagai Bahan Baku
Pembuatan Membran untuk Desalinasi Air Laut. Tugas Akhir. Jurusan Teknik Lingkungan Fakultas Teknik Sipil dan Perencanaan Institut Teknologi Sepuluh Nopember. Surabaya.

Grady, C.P.L dan Lim, H.C., 1980, "Biological Wastewater Treatment”, Marcel Dekker Inc. New York.

Herlambang. A., 2002, Teknologi Pengolahan Limbah Cair Industri Tahu. Pusat Pengkajian dan Penerapan Teknologi Lingkungan (BPPT) dan Badan Pengendalian Dampak Lingkungan Samarinda.

Irmanto dan Suyata, 2007, Penurunan Kadar Amonia, Nitrit, dan Nitrat Limbah Cair Tahu di Desa Kalisari, Cilongok menggunakan Sistem Zeolit Teraktivasi dan Terimpregnasi $\mathrm{TiO}_{2}$.

Irmanto dan Suyata, 2009, Penurunan Kadar Amonia, Nitrir, dan Nitrat Limbah Cair Industri Tahu Menggunakan Arang Aktif dari Ampas Kopi, UNSOED, Purwokwerto.

Kaswinarni, 2007, Kajian Teknik Pengolahan Limbah Padat dan Cair Industri Tahu. Tesis Ilmu Lingkungan UNDIP: Semarang.

Keputusan Mentri Lingkungan Hidup No. 51 Tahun 1995. Baku Mutu Limbah Cair Bagi Kegiatan Industri.

Li, Y., Chung, T. dan Kulprathipanja, S., 2007, Novel Ag+-zeolite/polymer mixed matrix membranes with a high $\mathrm{CO}_{2} / \mathrm{CH}_{4}$ selectivity, AIChE J., 53, 610616.

Mabande, G.T.P., Pradhan, G., Schwieger, W., Hanebuth, M., Dittmeyer, R.T., Selvam, Zampieri, A., Baser, H., Herrmann, R., 2004, A study of Silicalite-1 and AlZSM-5 membrane synthesis on stainless 
steel supports, Microporous and Mesoporous Materials, 75, 209

Muliawati, 2012, Pembuatan dan Karakteristik Membran Nanofiltrasi untuk Pengolahan Air, Undip, Semarang.

Mumpuni, 2011, Pembuatan Membran Komposit Pervaporasi Berbasis Poliether Sulfone-Biopolimer Untuk Dehidrasi Bioethanol. Thesis teknik kimia. Universitas Diponegoro. Semarang.

Mulder, M., 1996, Basic Principles of Membran Technology, second edition, Kluwer Academic Publishers, Chapter 1 : Introduction, pp. 7

Myrasandri, P dan Syafila, M., 2012, Degradasi Senyawa Organik Limbah Cair Tahu Dalam Anaerobic. Baffled Reactor. Tugas Akhir Teknik Lingkungan ITB: Bandung.

Notodarmojo, S., Zulkarnain, T., Mayashanthy, D dan Irsyad, M., 2004, Efek Pretreatment Terhadap Pembentukan Lapisan Cake dan Struktur Membrane pada Membran Ultrafiltrasi Aliran Cross-flow dalam Pengolahan Limbah Cair Emulsi Minyak. Departemen Teknik Lingkungan Fakultas Teknik Sipil dan Perencanaan ITB. Jurnal PROC ITB Sains \& Tek. Vol 36:2

Puspayana D.R. dan Damayanti A., 2013, Pengolahan Limbah Cair Tahu Menggunakan Membran Nanofiltrasi Silika Aliran Cross Flow untuk Menurunakan Kadar Nitrat dan Amonium, Institut Teknologi Sepuluh Nopember, Surabaya.

Rossiana, N., 2006, Uji Toksisitas Limbah Cair Tahu Sumedang terhadap Reproduksi Daphnia carinata KING. Jurnal Biologi. Jurusan Biologi Fakultas Matematika dan Ilmu Pengetahuan Alam Universitas Padjajaran: Bandung
Said, N., I., 2009, Uji Kinerja Pengolahan Air Siap Minum dengan Proses Biofiltrasi , Ultrafiltrasi, dan Reverse Osmosis (RO) dengan Air Baku Sungai, Pusat Teknologi Lingkungan BPPT, Jakarta Pusat.

Saljoughi E., 2010, Effect of PEG additive and coagulation bath temperatureon the morphology permeability and thermal/chemical stability of asymmetric CAmembranes. Vol.262. hlm 72-78.

Shan, W. Y., Zhang, W., Yang, C., Ke, Z., Gao, Y., Ye, Y., Tang , 2004, Electrophoretic deposition of nanosized zeolites in non-aqueous medium and its application in fabricating thin zeolite membrans, Microporous and Mesoporous Material, 69, 35-42.

Steenkamp, G.C., Nijmeijer, A., Krieg, H.M., Keizer, K., 2001, Centrifugal casting of ceramic membrane tubes and coating with chitosan, Separation and Purification Tegnology, 25, 407

Su Y.L., Wei Cheng, Chao Li, dan Zhongyi Jiang, 2009, Preparation of antifouling ultrafiltration membranes with poly(ethylene glycol)-graftpolyacrylonitril copolymers. Elsevier. Journal of Membrane Science. Page : 246-252

Sugiharto, 1987, Dasar-Dasar Pengolahan Air Limbah. UI Press. Jakarta.

Sutherland, K., 2008, What is Nanofiltration? Filtration and Separation 45(8), 32-35. (this presents approaches to the study of nanotechnology concept)

Ulbricht, M., 2006, Advanced functional polymer membrans, Polymer, 47, 22172262

Wang P., Huang P., Xu N., Shi J., Lin Y.S., 1999, Effects of sintering temperature 
on properties of alumina microfiltration membranes, Journal of Membrane Science, 155, 309
Wilson, R.W.; Murphy,K.L.; Sutton,P .M.; Lackey,S.L., 1981 : Design and cost comparison of Biological nitrogen removal processes, Journal of the Water Pollution Control Federation 53:1294-1 